\title{
Management of employee wellness in South Africa: Employer, service provider and union perspectives
}

\author{
Authors: \\ Charlotte Sieberhagen ${ }^{1}$ \\ Jaco Pienaar ${ }^{1}$ \\ Crizelle Els ${ }^{1}$

\section{Affiliations:} \\ ${ }^{1}$ WorkWell: Research Unit for \\ Economic and Management \\ Sciences, North-West \\ University, Potchefstroom, \\ South Africa \\ Correspondence to: \\ Jaco Pienaar \\ Email: \\ Jaco.Pienaar@nwu.ac.za \\ Postal address: \\ Private Bag X6001, \\ Potchefstroom 2520, \\ South Africa \\ Dates: \\ Received: 18 May 2010 \\ Accepted: 22 Feb. 2011 \\ Published: 23 June 2011 \\ How to cite this article: \\ Sieberhagen, C., Pienaar, \\ J., \& Els, C. (2011). \\ Management of employee \\ wellness in South Africa: \\ Employer, service provider \\ and union perspectives. $S A$ \\ Journal of Human Resource \\ Management/SA Tydskrif vir \\ Menslikehulpbronbestuur, \\ 9(1), Art. \#305, 14 pages. doi: \\ 10.4102/sajhrm.v9i1.305
}

(C) 2011. The Authors Licensee: OpenJournals Publishing. This work is licensed under the Creative Commons Attribution License.
Orientation: This article focuses on how South African organisations manage their employees' wellness through their Employee Wellness Programmes (EWPs).

Research purpose: The objective of this research is to describe employee wellness in South Africa by investigating the types, foci and perceived success of EWPs.

Motivation for the study: Despite the growing awareness of the importance of EWPs in South Africa, the nature, content, context, participants, role-players and anticipated benefits as well as the possible drawbacks of these programmes in the South African context are unclear.

Research design, approach and method: The researchers used a cross-sectional design. The first author developed the Employee Wellness Survey, consisting of quantitative and qualitative questions, to collect data from 16 organisations, four service providers and seven labour unions in South Africa.

Main findings: The results showed that organisations, service providers and labour unions define employee wellness differently and that these role players give different reasons for introducing EWPs. Almost half of the participating organisations have no baseline measurement with which to compare the effectiveness of their EWPs. Generally, all the organisations present the results of their programmes reasonably. However, the programmes involve little overall expenditure to the organisations.

Practical/managerial implications: Organisations should monitor the state of their employees' wellness in order to manage it effectively. This will only become possible when information about employee wellness improves.

Contribution/value-add: This study provides new information about the nature, content, context, participants, role-players, anticipated benefits and possible drawbacks of EWPs in the South-African context.

\section{Introduction}

\section{Key focus of the study}

There is no universally accepted definition of employee wellness. In addition, there is little research to address the best practices for managing EWPs. This poses great challenges for benchmarking the effectiveness of an organisation's EWP. This article aims to provide insights into the nature, content, context, participants, role-players and anticipated benefits and possible drawbacks of EWPs as organisations implement them in South Africa.

\section{Background to the study}

Wellness is a badly defined concept in the literature because there is little agreement about what a definition should contain. Definitions include:

- 'a conscious and deliberate approach to an advanced state of physical, psychological, and spiritual health' (Ardell, 1985, p. 38)

- 'a multidimensional state of being describing the existence of positive health in an individual as exemplified by quality of life and a sense of well-being' (Corbin \& Pangrazi, 2001, p. 3).

Corbin, Lindey, Welk and Corbin (2002) describe wellness as a person's state of well-being that contributes to an improved quality of life. In addition, the literature uses the terms wellness and well-being interchangeably (Korhonen et al., 1998; Martin, Kirkcaldy \& Siefen, 2003). This absence of a universal definition, and confusion about a preferred term to describe wellness, pose great difficulties to developing guidelines for good wellness practices in organisations. 


\section{Trends from the literature}

Organisations are currently becoming more aware of issues related to employee wellness or well-being (Hooper, 2004) and there is increased public interest in integrating wellness activities with employers' responsibilities (Hillier, Fewell, Cann \& Shephard, 2005). This move towards healthy workplaces and empowered employees mirrors trends between positive psychological states and organisational well-being (Maslach, Schaufeli \& Leiter, 2001; Van Den Bergh, 2000).

This has led to the introduction of various programmes. They include Employee Assistance Programmes (EAPs) and EWPs to address wellness issues in the workplace. According to Berridge and Cooper (1994) an EAP is:

a programmatic intervention at the workplace, usually at the level of the individual employee using behavioural science knowledge and methods for the recognition and control of certain work- and non work-related problems.

(Berridge \& Cooper, 1994, p. 5)

Other authors have described EAPs as programmes that cover the identification, assessment, monitoring, referral, counselling, and follow-up activities that aim at addressing employees' problems (Ramanathan, 1992; White, McDuff, Schwartz, Tiegel \& Judge, 1996; Zarkin, Bray \& Qi, 2000).

Wellness programmes are intervention strategies intended to promote the well-being of employees. They could be curative and preventative in nature. The purpose of introducing a wellness programme in an organisation is to create an awareness of wellness issues, to facilitate personal change and health management and to promote a healthy and supportive workplace (Anonymous, 2007).

These definitions of EAPs and EWPs make it clear that these two types of programmes address similar issues about employee wellness. This article will use EWPs to describe programmes intended to improve employee wellness and well-being.

When an organisation introduces an EWP, it allows employees to take charge of, and responsibility for, their own well-being (Derr \& Lindsay, 1999). According to Leiter and Wahlen (1996), EWPs typically include activities that focus on relieving the stress of employees that personal finances, substance abuse, health problems, career crises and job demands cause.

The support employees receive from their organisations through EWPs presents great benefits to those who use these programmes. They include increased mental wellness, energy, resilience, life and job satisfaction as well as reduced stress and depression (Renaud et al., 2008; ThøgersenNtoumani \& Fox, 2005). The benefits organisations derive from their EWPs include (Addley, McQuillan \& Ruddle, 2001; Allen, 1993; Andrew, 1999; Goetzel \& Ozminkowski, 2008; Hemp, 2004; Makrides, 2004; Naidoo \& Jano, 2003; Shaw, Alfonso, Howat \& Corben, 2007; Thøgersen-Ntoumani \& Fox, 2005):
- reduced absenteeism

- increased presenteeism

- meeting labour legislation requirements

- improved industrial relations

- increased employee performance and productivity

- reduced health care costs

- a reduction in accidents.

Therefore, Naidoo and Jano (2003) suggest that organisations should approach problems in a structured way, focusing on the employee and on the organisation. The reasoning behind this approach is that the wellness of an employee can influence the wellness of an organisation, and vice versa.

The success and effectiveness of EWPs depend on a number of factors, including the rationale, use and evaluation of the programmes. Various researchers emphasise the importance of a needs analysis to identify the stressors and issues that employees experience. Organisations should conduct this needs analysis before designing and introducing an EWP. This will allow them to target issues that they need to address accurately (Berridge, Cooper \& Highley-Marchington, 1997).

It is essential to determine the utilisation rate as the reasons employees give as to why they participate in or ignore EWPs will provide valuable information about the effectiveness of the programmes. According to Highley and Cooper (1994, p. 49), the importance of evaluating EWPs cannot be overestimated. Primarily, the purposes of evaluating EWPs are to justify their existence, to determine the extent to which they achieve their objectives and to find ways of improving their effectiveness. Incorrect measures that organisations use to evaluate the effectiveness of EWPs could result in their drawing inaccurate conclusions from their evaluations.

\section{A brief history of Employee Wellness Programmes in South Africa}

This article focuses on the way(s) South African organisations manage their EWPs in order to keep their employees well at work. EWPs in South Africa only started to emerge in the 1980s. The Chamber of Mines of South Africa initiated them after it carried out a feasibility study in the mining industry in 1983 (Terblanche, 1992).

This feasibility study is a milestone in the development of EWPs in South Africa. Resistance to them was clear when they first appeared. This was because many thought that the people who used them were alcoholics (Gerber, 1995; Naidoo \& Jano, 2003). Participation in EWPs is also sometimes problematic because employees do not trust their confidentiality. Furthermore, employees see participation in an EWP as another demand rather than as a resource (Myers, 1984; Taute \& Manzini, 2009).

Fewer than half of South Africa's top 100 organisations have EWPs, despite the important roles these programmes can play in promoting employee health and wellness and in assisting organisations and employees to adjust to rapidly changing contexts (Naidoo \& Jano, 2003). 
Terblanche (1992) conducted a survey to determine the conceptual sophistication of EWPs in the South African business community. According to the survey, only $69 \%$ of employer respondents actually offered direct assistance to their employees. Of this percentage, only $58 \%$ offered it in structured programmes. Considering the significant changes in the South African organisational landscape since the advent of democracy, the shortage of EWPs in South Africa is alarming because change is a factor that greatly reduces wellness at work (Hillier et al., 2005).

When EWPs do exist, they are often not part of core business structures (Bennett, 1999). This suggests that organisations do not realise the extent to which employee wellness contributes to organisations' bottom line. Organisations that invest time and resources in an employee wellness culture, with the focus on being proactive rather than reactive, can expect a return on the investment. The possible return on investment might include lower absenteeism, healthier employees, fewer accidents and lower staff turnover (Dhanesar \& Hales, 1994).

Based on the problem stated above, the general aim of this research is to describe the management of employee wellness in South Africa by investigating the types, foci and successes of employee health and wellness programmes.

\section{Research objectives}

The objectives of this study are to:

- define employee wellness as it currently exists in selected South African organisations

- determine the reasons why organisations introduce Employee Wellness Programmes and the problems they experience in doing so

- investigate how the organisations present the results of their programmes

- investigate how organisations rate the success and effectiveness of their EWPs

- determine employee needs and participation of employees in EWPs

- determine how organisations fund their programmes

- to investigate how managers are involved in managing EWPs in their organisations.

\section{The possible value of the study}

Employee wellness is a badly defined construct in industrial psychology. There is also a lack of research on specific practices in South African organisations to promote employee wellness.

This article contributes to research in industrial psychology because it is a baseline study on how employee wellness practices function in South African organisations.

The study also concludes how organisations, labour unions and providers of employee wellness services define employee wellness in the South African context.
The sections that follow describe the research approach, research participants, measuring instruments and statistical analyses. The article presents the results of the study. A discussion of the results follows. Finally, it draws conclusions and makes recommendations.

\section{Research design Research approach}

The researchers used a mixed method design. They used a survey that contained quantitative and qualitative questions.

The researchers used a cross-sectional design. The first researcher drew a sample from the available population at a particular point in time (Shaughnessy \& Zechmeister, 1997). A cross-sectional design allowed them to use the information they collected to describe a population at that time and to assess interrelationships between variables within that population.

\section{Research method Research participants}

The participants consisted of organisations that contribute to employee wellness in various sectors of South Africa.

The researchers used a purposive sampling technique to select organisations that use the term 'wellness programme' when referring to programmes that address employee wellness or well-being.

The researchers targeted 16 organisations $(n=16)$. Of these, six were public companies and four were private. The other six organisations consisted of multinational companies, joint ventures, national departments and universities. Four of the organisations were from the transport, storage and communications sector and two from each of the manufacturing and education sectors. Five of the organisations have between 1001 and 3000 employees and four have between 5001 and 10000 .

Four of the organisations did not want to disclose their annual turnover. However, two of the organisations indicated that their annual turnover was between R1000 and R1250 million, whilst another two organisations had turnovers of more than R3500 million per annum.

Eight of the organisations could not provide information about their annual payroll as a percentage of annual turnover. However, for the organisations where this information was available, three indicated that their annual payroll, as a percentage of annual turnover, ranged between 31\% and $40 \%$. Only four of the organisations were established after 1994. The youngest organisation is only six years old whilst the oldest has been operating for over a century.

All of the participating organisations were registered at their relevant Sector Education and Training Authority (SETA) for skills development purposes. SETAs ensure that the 
various sectors identify their skills requirements and that the adequate and appropriate skills are readily available. However, 11 of the organisations were unable to provide information about their monthly skills levies.

In addition, the researchers incorporated the opinions of four service providers $(n=4)$ on employee wellness in South Africa. Two of them provided services to between 201 and 500 organisations. The smallest indicated that they provided services to between five and 10 organisations, whilst the service provider with the second largest customer base indicated that it services between 11 and 50 organisations. The oldest service provider was nine years old and the youngest only two.

The researchers also approached seven labour unions $(n=7)$, in order to incorporate their opinions on employee wellness in South Africa into a holistic understanding of employee wellness management. Of these labour unions, four had members in all the sectors. The membership of the smallest was between 3001 and 5000, whilst the largest union had more than 500000 members. The oldest union is more than 100 years old and was established in 1905 . The youngest was established in 2001. Three of the unions were established after 1994.

\section{Measuring instruments}

The primary researcher developed the Employee Wellness Survey to determine the nature, content, context, participants, role players, anticipated benefits and possible drawbacks of a wellness programme in each organisation. This survey included quantitative items and qualitative questions that required further explanation.

To ensure its content validity, the researchers developed the questionnaire from the literature study. Over a period of two years (2007-2008), the researchers sent the questionnaire to experts in the field of employee wellness (both in the academia and organisations) to judge its face validity. They used a trial run to assess whether the items were understandable and to detect problems in the questionnaire. The questionnaire was divided into five sections:

- Section 1 contained information about the organisations, including their types, sectors of operations, annual turnover, number of full-time employees and the SETAs where they are registered.

- Section 2 contained reasons for introducing EWPs, their functions and perceived successes. For example, the researchers asked organisations to rate, on a 5-point Likert scale, 'How successful is your Employee Wellness Programme?' They then asked the organisations to give reasons to support their evaluations of their EWPs.

- Section 3 contained information about the effectiveness, activities and levels of employee participation in EWPs. For example, the researchers asked organisations 'How is the effectiveness of the Employee Wellness Programme determined?'
- Section 4 contained information about organisations' contributions, strikes, absenteeism and staff turnover. For example, the researchers asked 'How many days sick leave were taken in the last 12 months for the organisation as a whole?' They then asked organisations to give the five main reasons for the sick leave.

- Section 5 contained information about budgets, needs analyses and the foci of the organisations' EWPs. For example, the researchers asked the organisations to indicate 'what is the total annual budget allocated to the Employee Wellness Programme in your organisation?' and 'on which activities in the Employee Wellness Programme do you spend most of your budget?'

The primary researcher developed the Employee Wellness Survey (Service Providers) to determine how many organisations they provide services to, the nature of the services they provide and how they define employee wellness.

The primary researcher developed the Employee Wellness Survey (Labour Unions) to determine the sectors in which the labour unions operate, how many members they have, how they define employee wellness and how they influence employee wellness issues in their members' organisations.

\section{Research procedure}

The researchers invited the people responsible for managing EWPs in some of the more prominent organisations in South Africa and in some state institutions $(n=16)$, to participate in this study. They targeted only those organisations that use the term 'wellness programme' to refer to activities related to improving employee wellness.

The researchers also targeted labour unions and service providers. They surveyed seven labour unions and four service providers to explore their definitions of employee wellness in South Africa. They also asked the four service providers to describe the nature of the employee wellness services they provide in South Africa.

The researchers hoped to obtain to gain a good idea of the current situation about employee wellness practices in South Africa from all major stakeholders.

\section{Statistical analysis}

The researchers performed the statistical analysis with the help of the SPSS programme (SPSS, 2007). They used descriptive statistics (means, frequency counts and percentages) to analyse the data. They regarded descriptive statistics as suitable and sufficient for this analysis because the aim of the study was descriptive in nature.

Where participants gave qualitative answers, the researchers used codes to extract themes. The researchers transcribed the telephone interviews they held with the organisations, labour unions and service providers and extracted descriptive quotations. They then extracted themes from them. 


\section{Results}

\section{Employee wellness as participating organisations, service providers and labour unions define it}

The heads of EWPs in the 16 participating organisations defined employee wellness.

The researchers first categorised the dimensions by grouping similar responses. After they had grouped the responses, they allocated a name to describe the dimension. The researchers identified 14 dimensions of employee wellness based on the responses from the participating organisations, service providers and labour unions. These 14 dimensions were:

- Health: This dimension includes information about employee health, medical issues, human immunodeficiency virus (HIV) management and organisational wellness. It refers to the improvements in the health of the employees in the organisation as part of the organisation's definition of employee wellness.

- Occupational health and safety (OHS): This dimension includes items, like work safety and the environment in which employees work, which can influence employee wellness in their organisations. Occupational health and safety is a component of how the participating organisations define employee wellness.

- Dimensions of wellness: This dimension includes items relating to the psychological, physical, financial, spiritual and social aspects of wellness. Further information included wellness as a continuum that ranges from unwell to well and wellness as a concept.

- Work wellness: This dimension included information about employee happiness at work, workers enjoying occupational wellness and efficient work styles. The definitions were work related.

- Self-development: This dimension included items that concern the growth, self-development and personal improvement of all employees so that they can reach their potentials through training. Generically, the definitions of employee wellness referred to the development of the employee in some way.

- Employee benefits: This dimension included items like the social, insurance, funeral and other benefits employees enjoy as part of their remuneration package. These all refer to benefits that organisations should offer employees in order to influence employee wellness.

- Legal requirements: This dimension related to the legal imperatives for employee wellness. Participants referred to the Basic Conditions of Employment Act, the Occupational Health and Safety Act, the Labour Relations Act (LRA) and general labour relations. These items all refer to the legal requirements with which organisations need to comply in order to facilitate employee wellness.

- Performance: This dimension included items that cover employees' performance, productivity, motivation, commitment, lifestyles, engagement, employees' sense of coherence, staff morale, vitality, meaning and purpose. These items all referred to improved employee performance.
- Recognition of joint benefits: This dimension involved the benefits of wellness to both organisations and employees, their shared responsibilities, reducing absenteeism, achieving balance, reducing the possible negative effects of unhealthy employees on the organisation and reducing the effects of an unhealthy organisation on its employees. These items all referred to the positive influence that employee wellness should have on the organisation and on employees if there is employee wellness in the organisation.

- Employee services: This dimension covered the services that were available to employees. It included services like counselling, leave for family responsibilities, general employee services as well as specialised treatment and support. These items referred to services that promote employee wellness in organisations.

- Employee responsibility: This dimension focused on the employees' responsibility for their own wellness. Organisations felt that employee wellness was the responsibility of employees.

- Wellness management: This dimension covers managing wellness. Organisations felt that identifying and rectifying existing problems are components of employee wellness. Management activities that participants included were managing behavioural risk, recognising that this is a continuous process, that organisations can manage wellness, identify and rectify problems and identify risks. Participants referred to organisational, interpersonal and personal levels.

- Stress: This dimension refers to the interaction between job demands and job resources as well as employees' stress and distress. Organisations felt that they should address these issues in order to promote employee wellness.

- Holistic: This dimension referred to the perception that wellness efforts need to be holistic, integrated and have a wide focus. Organisations felt that they should take a broad view of employees.

Table 1 shows the dimensions that organisations used to define employee wellness. Seven of the organisations referred to three dimensions only when they defined employee wellness. Half of the organisations referred to 'health' and nine organisations referred to the 'dimensions of wellness' in their definitions of employee wellness.

Table 2 shows how the participating service providers defined employee wellness according to the 14 dimensions. Only two of the service providers referred to 'work wellness' and to 'positive work influences' in their definitions. Two of the service providers referred to 'employee responsibility' in their definitions.

Table 3 shows how the seven participating labour unions defined employee wellness according to the dimensions of wellness. Four referred to 'health' in their definitions of employee wellness and four to 'occupational health and safety'. Five of the labour unions referred to 'legal requirements' and only one referred to 'employee responsibility'. 
TABLE 1: Employee health according to participating organisations, service providers and labour unions.

\begin{tabular}{|c|c|}
\hline Dimension & Items \\
\hline Health & - Health, medical, HIV and organisational health \\
\hline Occupational health and safety & - Safety and environment \\
\hline Dimensions of wellness & $\begin{array}{l}\text { - Mental, psychological, emotional and mind } \\
\text { - Financial } \\
\text { - Physical or body } \\
\text { - Well-being or the wellness of employees } \\
\text { - Social dimensions of wellness } \\
\text { - Spiritual } \\
\text { - Wellness as a continuum } \\
\text { - Wellness as a concept }\end{array}$ \\
\hline Work wellness & $\begin{array}{l}\text { - Happiness at work, occupational wellness, } \\
\text { work style and organisational wellness }\end{array}$ \\
\hline Self development & $\begin{array}{l}\text { - Growth or self development, improving } \\
\text { employees, reaching full capacity and training }\end{array}$ \\
\hline Employee benefits & - Social benefits (insurance, funeral and policies) \\
\hline Legal requirements & $\begin{array}{l}\text { - Basic, OHS, LRA, labour relations and other } \\
\text { legal requirements }\end{array}$ \\
\hline Performance & $\begin{array}{l}\text { - Productivity, motivation, committed lifestyle, } \\
\text { engagement, sense of coherence, staff morale, } \\
\text { vitality, meaning and purpose }\end{array}$ \\
\hline Recognition of dual benefits & $\begin{array}{l}\text { - Benefits to both organisations and employees, } \\
\text { shared responsibilities, reducing absenteeism, } \\
\text { balance, reducing the negative effects of } \\
\text { employees on organisations and reducing the } \\
\text { negative effects of organisations on employees }\end{array}$ \\
\hline Employee services & $\begin{array}{l}\text { - Counselling, family responsibilities, employee } \\
\text { services, specialised treatment and support }\end{array}$ \\
\hline Employee responsibility & $\begin{array}{l}\text { - Employee responsibilities, employees and } \\
\text { personal }\end{array}$ \\
\hline Wellness management & $\begin{array}{l}\text { - Managing behaviour risk continuously, } \\
\text { managing wellness, identifying problems } \\
\text { and risk as well as rectifying problems at } \\
\text { organisational and personal levels }\end{array}$ \\
\hline Stress & $\begin{array}{l}\text { - Interaction between job demands and job } \\
\text { resources, stress and distress }\end{array}$ \\
\hline Holistic & - Holistic, wide focus and integrated processes \\
\hline
\end{tabular}

OHS, occupational health and safety; LRA, labour relations act.

TABLE 2: Definitions of employee wellness according to participating service providers.

\begin{tabular}{ll}
\hline Service provider & Definitions \\
\hline 1 & - Health \\
& - Recognition of dual benefits \\
& - Employee responsibility \\
& - Positive work influences \\
& - Holistic \\
- Legal requirements & - Work wellness \\
& - Dimension of wellness \\
& - Recognition of dual benefits \\
& - Positive work influences \\
& - Self development \\
& - Employee responsibility \\
& - Work wellness \\
& - Recognition of dual benefits \\
& - Wellness management \\
\hline
\end{tabular}

\section{Reasons for introducing Employee Wellness Programmes according to participating organisations, service providers and labour unions}

Table 4 gives the reasons for introducing Employee Wellness Programmes according to the participating organisations, service providers and labour unions.
TABLE 3: Definitions of employee wellness according to participating labour unions.

\begin{tabular}{|c|c|}
\hline Labour union & Definitions \\
\hline 1 & $\begin{array}{l}\text { - Health } \\
\text { - OHS } \\
\text { - Work wellness }\end{array}$ \\
\hline 2 & $\begin{array}{l}\text { - Health } \\
\text { - Dimensions of wellness }\end{array}$ \\
\hline 3 & $\begin{array}{l}\text { - OHS } \\
\text { - Work wellness } \\
\text { - Positive work influences } \\
\text { - Self development } \\
\text { - Legal requirements }\end{array}$ \\
\hline 4 & $\begin{array}{l}\text { - Employee services } \\
\text { - Employee benefits } \\
\text { - Legal requirements }\end{array}$ \\
\hline 5 & $\begin{array}{l}\text { - Health } \\
\text { - OHS } \\
\text { - Legal requirements }\end{array}$ \\
\hline 6 & $\begin{array}{l}\text { - Health } \\
\text { - Employee benefits } \\
\text { - Legal requirements } \\
\text { - Holistic }\end{array}$ \\
\hline 7 & $\begin{array}{l}\text { - OHS } \\
\text { - Legal requirements } \\
\text { - Self development } \\
\text { - Employee responsibilities }\end{array}$ \\
\hline
\end{tabular}

$\mathrm{OHS}$, occupational health and safety.

Table 4 shows that, for the participating organisations, the main reason for introducing EWPs was the high incidence of sick leave. The second group of reasons was high rates of absenteeism and social responsibility. The third group of reasons was to address stress, meet employees' needs for services, because of human relations (HR) incidents or because of the high numbers of people who were working overtime.

The main reasons that the participating service providers thought that the organisations they serve introduced EWPs were social responsibility, in order to become employers of choice and compliance with OHS law.

According to labour unions, the reasons why their members' employers introduced EWPs were to make their employees more productive, social responsibility, compliance with OHS law and to retain employees.

\section{Introduction dates}

Of the 16 organisations, 14 introduced their EWPs after 2000. One organisation did not know when it introduced its programme and one organisation's programme has been running since 1970.

\section{Negative consequences of introducing}

When asked about the negative consequences of introducing their EWPs, eight of the 16 organisations mentioned that introducing the programmes did not have any negative consequences. The other half indicated that it did have negative consequences.

The reasons the eight organisations that experienced negative consequences included trust and confidentiality 
TABLE 4: Reasons for introducing Employee Wellness Programmes.

\begin{tabular}{|c|c|c|c|c|c|c|}
\hline \multirow[t]{2}{*}{ Item } & \multicolumn{2}{|c|}{ Participating organisations } & \multicolumn{2}{|c|}{ Participating service providers } & \multicolumn{2}{|c|}{ Participating labour unions } \\
\hline & $F$ & $\%$ & $\boldsymbol{F}$ & $\%$ & $F$ & $\%$ \\
\hline High incidence of sick leave & 5 & 10.9 & - & - & - & - \\
\hline Social responsibility & 4 & 8.7 & 2 & 16.7 & 2 & 14.3 \\
\hline High absenteeism & 4 & 8.7 & - & - & - & - \\
\hline Address stress & 3 & 6.5 & - & - & - & - \\
\hline Employees' need for services & 3 & 6.5 & - & - & - & - \\
\hline Human relations incidents & 3 & 6.5 & - & - & - & - \\
\hline High number of people working overtime & 3 & 6.5 & - & - & - & - \\
\hline OHS law compliance & 2 & 4.3 & 2 & 16.7 & 2 & 14.3 \\
\hline HIV and Aids legislation & 2 & 4.3 & 1 & 8.3 & - & - \\
\hline Make employees more productive & 2 & 4.3 & 1 & 8.3 & 5 & 35.7 \\
\hline Managers thought it necessary & 2 & 4.3 & - & - & - & - \\
\hline High number of accidents & 2 & 4.3 & - & - & - & - \\
\hline Become employers of choice & 1 & 2.2 & 2 & 16.7 & - & - \\
\hline Approach problems proactively & 1 & 2.2 & 1 & 8.3 & - & - \\
\hline Retain employees & 1 & 2.2 & - & - & 2 & 14.3 \\
\hline Outcome of wellness assessment & 1 & 2.2 & - & - & - & - \\
\hline Organisational change & 1 & 2.2 & - & - & - & - \\
\hline Work or life balance & 1 & 2.2 & - & - & - & - \\
\hline $\begin{array}{l}\text { Employee should not have excuses for not being } \\
\text { productive }\end{array}$ & 1 & 2.2 & - & - & - & - \\
\hline Wellness should make financial sense & 1 & 2.2 & - & - & - & - \\
\hline Annual medical for employees working with food & 1 & 2.2 & - & - & - & - \\
\hline Union pressure & 1 & 2.2 & - & - & - & - \\
\hline New legislation & 1 & 2.2 & - & - & - & - \\
\hline Reduce medical costs & - & - & 1 & 8.3 & 1 & 7.1 \\
\hline Influence bottom line & - & - & 1 & 8.3 & 1 & 7.1 \\
\hline Dual benefits for employee and employer & - & - & - & - & 1 & 7.1 \\
\hline
\end{tabular}

$F$, frequency; AIDS, acquired immunodeficiency syndrome; HIV, human immunodeficiency virus; OHS, occupational health and safety.

issues (four organisations). Implementation and logistical problems because of remote locations (three organisations) were the second most noted reasons. Other reasons for negative consequences included staff members' insensitivity towards employees (one organisation), a low uptake on the programme (one organisation) and managers' concerns that they were 'getting soft' (one organisation).

\section{Reasons why organisations rated their Employee Wellness Programmes as successful}

In rating the effectiveness of their organisations' EWPs, 10 of the participating organisations rated their programmes as $70 \%$ successful, or higher. Of the remainder, three rated their programmes as $60 \%$ successful and two of the organisations gave their programme a rating of only $50 \%$. One organisation indicated that it could not rate its programme yet.

Table 5 shows that the reasons organisations gave for their ratings differed from one organisation to the next. Three of the organisations, which rated their programmes as $70 \%$ or higher, gave a reduction in absenteeism as the reason. Organisation 13 attributed its rating of $50 \%$ as problems with its service provider and because wellness, it asserts, is not measurable. Organisation 6 gave no reason for its rating of $60 \%$.

The researchers allowed the organisations that gave their programmes a poor rating to give reasons for their rating. Table 6 gives these reasons.
Three organisations indicated that assessing their programme was a problem. Two of the organisations that gave the poorest ratings to their programmes attributed them to measurability. Organisation 14 also indicated that it was not able to measure the outcomes of its programme. This made it difficult for the organisation to measure the effectiveness of its programme. However, organisation 14 still rated it $70 \%$ and higher.

\section{Measuring the effectiveness of programmes}

Seven of the 16 organisations do not measure the effectiveness of their EWPs, but they do look at aspects like utilisation rates, absenteeism, reporting of chronic diseases and buy-in. Although they considered these aspects, the organisations asserted that they are not true measures of effectiveness. One organisation stated that it could not measure the effectiveness of its programme because of a problem with the report from the service provider. Nine of the organisations indicated that they did measure the effectiveness of their EWPs by considering utilisation rates, feedback from staff and measuring absenteeism.

\section{Improving Employee Wellness Programmes delivery}

Fourteen of the organisations felt that they could improve the delivery of their EWPs. The researchers allowed the organisations to propose suggestions for improving delivery. Some of the suggestions were: 
TABLE 5: Reasons why Employee Wellness Programmes were successful.

\begin{tabular}{|c|c|c|}
\hline Organisation & Rating & Reasons \\
\hline 1 & $70 \%$ and higher & $\begin{array}{l}\text { - Good in-house EAP } \\
\text { - Network to solve problems } \\
\text { - Train line managers to EAP } \\
\text { - Services address staff needs } \\
\text { - HIV programme best in sector }\end{array}$ \\
\hline 2 & $70 \%$ and higher & $\begin{array}{l}\text { - Participation high } \\
\text { - High percentage of self referrals } \\
\text { - } 70 \% \text { of staff with HIV are on treatment }\end{array}$ \\
\hline 3 & $70 \%$ and higher & $\begin{array}{l}\text { - Services address staff needs } \\
\text { - Good counselling services } \\
\text { - Good health services } \\
\text { - Uses a service provider }\end{array}$ \\
\hline 4 & $60 \%$ & - Good counselling services \\
\hline 5 & $70 \%$ and higher & $\begin{array}{l}\text { - Conducted wellness assessment } \\
\text { - Feedback on assessment } \\
\text { - Implementing interventions } \\
\text { - Pro-active }\end{array}$ \\
\hline 6 & $60 \%$ & - No reasons \\
\hline 7 & $70 \%$ and higher & $\begin{array}{l}\text { - Reduction in absenteeism } \\
\text { - Voluntary testing }\end{array}$ \\
\hline 8 & $60 \%$ & - Participation high \\
\hline 9 & $70 \%$ and higher & $\begin{array}{l}\text { - Reduction in absenteeism } \\
\text { - High percentage of self referrals } \\
\text { - Staff feedback positive }\end{array}$ \\
\hline 10 & $70 \%$ and higher & $\begin{array}{l}\text { - High uptake on VCT } \\
\text { - Increased participation } \\
\text { - Support of executive members }\end{array}$ \\
\hline 11 & $70 \%$ and higher & $\begin{array}{l}\text { - Focus on psychosocial } \\
\text { - Good health services }\end{array}$ \\
\hline 12 & $70 \%$ and higher & $\begin{array}{l}\text { - Participation high } \\
\text { - Wellness days at branches } \\
\text { - HIV training high }\end{array}$ \\
\hline 13 & $50 \%$ & $\begin{array}{l}\text { - Reporting from service provider not } \\
\text { adequate } \\
\text { - Wellness not measurable } \\
\text { - Reports from service provider gives poor } \\
\text { information } \\
\text { - Service provider cannot cope with } \\
\text { emergencies }\end{array}$ \\
\hline 14 & $50 \%$ & $\begin{array}{l}\text { - Staff feedback positive } \\
\text { - Raised awareness } \\
\text { - Good counselling services }\end{array}$ \\
\hline 15 & Not rated & - Not yet rateable \\
\hline 16 & $70 \%$ and higher & $\begin{array}{l}\text { - Suicide dramatically down } \\
\text { - Used in senior selection } \\
\text { - Reduction in absenteeism } \\
\text { - Medical incapacity reduced }\end{array}$ \\
\hline
\end{tabular}

HIV, human immunodeficiency virus; EAP, employee assistance programmes; VCT, voluntary counselling and testing.

TABLE 6: Reasons for rating employee wellness programmes as less successful.

\begin{tabular}{|c|c|c|}
\hline Organisation & Rating & Negative reasons \\
\hline 4 & $60 \%$ & $\begin{array}{l}\text { - Not yet holistic } \\
\text { - Other areas, like stress, not yet developed }\end{array}$ \\
\hline 7 & $70 \%$ and higher & $\begin{array}{l}\text { - HIV is high } \\
\text { - New infection rate is high } \\
\text { - Safety record is low }\end{array}$ \\
\hline 9 & $70 \%$ and higher & - No measurable outcome \\
\hline 13 & $50 \%$ & $\begin{array}{l}\text { - Report from service provider not adequate } \\
\text { - Wellness not measurable } \\
\text { - Service provider cannot cope with } \\
\text { emergencies }\end{array}$ \\
\hline 14 & $50 \%$ & $\begin{array}{l}\text { - No measurable outcome } \\
\text { - Lack of knowledge about programme }\end{array}$ \\
\hline
\end{tabular}

HIV, human immunodeficiency virus.

- making their programmes more holistic and integrated (four organisations)

- allocating more resources and personnel (three organisations)
TABLE 7: How organisations measure the effectiveness of programmes.

\begin{tabular}{lll}
\hline Item & $\begin{array}{l}\text { Effectiveness not } \\
\text { measured }(\boldsymbol{n}=\mathbf{7})\end{array}$ & $\begin{array}{l}\text { Effectiveness } \\
\text { measured }(\boldsymbol{n}=\mathbf{9})\end{array}$ \\
\hline Utilisation rate & 2 & 4 \\
Absenteeism & 1 & 2 \\
Feedback from staff & - & 2 \\
HIV registration & - & 1 \\
People with HIV that return to work & 1 & - \\
Medical boardings down & - & 1 \\
Success of smoking cessation & - & 1 \\
Extensive marketing & - & 1 \\
Reaching more people & - & 1 \\
Psychological rate & - & 1 \\
Chronic disease reports from medical & 1 & - \\
aids & & - \\
Problems with reports from service & 1 & \\
providers & & - \\
Buy-in & 1 & 1 \\
Targeted projects focus on real needs & - & 1 \\
Good planning & - & 1 \\
Looking at different indicators & - & 1 \\
\hline Exit interviews & - & \\
Amount of suicides down & - & \\
\hline
\end{tabular}

HIV, human immunodeficiency virus.

TABLE 8: Percentage of employees who participate in their organisation's Employee Wellness Programmes.

\begin{tabular}{lll}
\hline Item & $\boldsymbol{F}$ & $\boldsymbol{\%}$ \\
\hline Unknown participation rate & 2 & 12.5 \\
$8 \%$ & 1 & 6.25 \\
$10 \%$ & 1 & 6.25 \\
$17 \%$ & 1 & 6.25 \\
$20 \%$ & 2 & 12.5 \\
$30 \%$ & 2 & 12.5 \\
$40 \%$ & 1 & 6.25 \\
$50 \%$ & 2 & 12.5 \\
Between $10 \%$ and $50 \%$ & 1 & 6.25 \\
$60 \%$ & 2 & 12.5 \\
$71 \%$ & 1 & 6.25 \\
\hline
\end{tabular}

$F$, frequency.

- providing the EWPs in-house (two organisations)

- that they need to assess their EWPs accurately (one organisation).

One organisation each expressed these needs:

- targeted interventions

- improved training

- follow-ups on interventions

- new ideas relevant to EWPs.

One organisation each suggested:

- a better return on investment

- providing more support to employees

- better communication and marketing

- better coordinator focus on wellness programmes.

In addition, one organisation reported that it was busy introducing an EWP.

\section{Determining employees' needs}

When asked how often organisations determine their employees' need for employee wellness, five of the 
organisations said they consult their employees monthly. Four conducted a quarterly needs analysis, three reported annual needs analyses, two determine their employees' needs every six months and the remaining two conducted needs analyses every two years.

The organisations reported that they use different ways to determine their employees' needs. They include:

- feedback and discussions with employees (eight organisations)

- inputs from employee wellness personnel (five organisations)

- $\quad$ surveys and questionnaires (four organisations)

- health risk assessments (four organisations)

- feedback from service providers (three organisations)

- inputs from managers (three organisations)

- organisational assessments (two organisations)

- feedback from unions (two organisations)

- considering trends and tendencies (one organisation)

- looking at the profiles of employees (one organisation).

\section{Participation rates of employees}

Table 8 gives the participation rates of employees in their respective organisations' EWPs.

Table 8 shows that two organisations could not provide participation rates, five of the organisations' participation rates were $20 \%$ and below, another five of the organisations' participation rates were between $30 \%$ and $50 \%$ and three of the organisations' participation rates were $60 \%$ and higher.

\section{Presenting the results of Employee Wellness Programmes}

Fourteen organisations presented the results of their EWPs to various stakeholders and at various times and events. Four organisations presented their results once a year, three presented their results twice a year, three presented them quarterly and two presented their results monthly. Two of the organisations presented their results on an ad hoc basis at executive meetings and one organisation presented the results after health days.

Some organisations presented the results of their EWPs at board meetings (two) or at business units (two). One organisation each presented its results at the corporate office, at council meetings, during employee wellness programme committee meetings, at executive meetings, in Parliament, at institutional meetings, at regional meetings and during senior management meetings. One organisation presented its results to all business unit managers and one organisation presented its results to the chief executive officer (CEO).

\section{Support from managers}

When asked to rate the support organisations receive from managers, two of the organisations rated the support they receive as 'excellent', 13 indicated 'good' and one reported their support as 'average'.

\section{Funding of Employee Wellness Programmes}

Most of the participating organisations (13 of 16), reported that they had budgets for their EWP activities. The allocated budgets ranged from R140 000 to R5 million per year. Three organisations used a flat rate - they paid a fixed amount per employee per year. The total amounts ranged between R38 000 and R1.4 million per year for all employees. This is equates to between R5 and R187 per employee. Seven of the organisations used a fee-for-service system and the costs ranged between R600 000 and R800 000. Only one organisation used a sponsorship of R17 000 to fund part of its programme. Four organisations used a combination of budget and fee-for-service to fund their programmes and one used a combination of budget and sponsorships.

Table 9 shows that the main activities on which organisations spend their budgets were HIV and health services (11 organisations), EAP providers (six organisations), wellness services (four organisations) and counselling (three organisations).

The main activities on which organisations spend their flat rate budgets were counselling, E-care (health tips and advice via the Internet), HIV and Aids as well as programmes to manage disease risk. The main activities on which organisations spend their fee-for-service budgets were alcohol abuse, wellness activities, HIV and Aids services, counselling and EAP providers.

Table 10 shows the percentage of annual payroll that organisations spend on EWPs.

Table 10 shows that six of the organisations spend less than $1 \%$ of their annual payrolls on EWPs. In three of the organisations, this percentage was between 1.1 and $2 \%$. Five of the organisations did not know the percentage of annual payroll they spent on the EWPs.

TABLE 9: Main activities on which organisations spend their budgets for Employee Wellness Programmes.

\begin{tabular}{lll}
\hline Item & $\boldsymbol{F}$ & $\mathbf{\%}$ \\
\hline HIV and health services & 11 & 37.9 \\
EAP providers & 6 & 20.7 \\
Wellness services & 4 & 13.8 \\
Counselling & 3 & 10.3 \\
Training & 2 & 6.9 \\
Assessment & 1 & 3.4 \\
Social responsibility & 1 & 3.4 \\
\hline
\end{tabular}

$F$, frequency; HIV, human immunodeficiency virus; EAP, employee asistance programmes.

TABLE 10: Percentage of annual payroll organisations spend on Employee Wellness Programmes.

\begin{tabular}{lll}
\hline Item & $\boldsymbol{F}$ & $\boldsymbol{\%}$ \\
\hline $0-1 \%$ & 6 & 37.5 \\
$1.1-2 \%$ & 3 & 18.75 \\
$2.1-3 \%$ & 1 & 6.25 \\
$31-4 \%$ & 1 & 6.25 \\
No information available & 5 & 31.25 \\
\hline
\end{tabular}

$F$, frequency. 
Thirteen of the organisations reported that their budgets for their EWPs increased from the previous year and two said their budgets were unchanged. Only one of the organisations reported that its budget decreased from the previous year. Furthermore, 13 of the organisations expected that their budgets would increase for the next year and two said they expected their budgets to remain the same. Only one of the organisations expected its budget to decrease for the next year.

\section{Discussion and recommendations}

This study had seven purposes:

- to define employee wellness as it currently exists in selected South African organisations

- to determine the reasons why organisations introduce Employee Wellness Programmes and the problems they experience in doing so

- to investigate how the organisations present the results of their programmes

- to investigate how organisations rate the success and effectiveness of their EWPs

- to determine employee needs and participation of employees in EWPs

- to determine how organisations fund their programmes.

- to investigate how managers are involved in managing EWPs in their organisations.

\section{Defining employee wellness}

Employee wellness is a badly defined concept in South Africa and around the world.

When the researchers asked the participating organisations, labour unions and service providers to define employee wellness, they identified 14 dimensions. To complicate the matter, none of the organisations, labour unions or service providers could agree on what employee wellness is. In short, 16 organisations, four service providers and seven labour unions defined employee wellness in 27 different ways.

Even when the researchers separated them into groups, the organisations, service providers or labour unions did not emphasise the same dimensions of employee wellness. Most of the organisations and service providers referred to 'dimensions of wellness' in their definitions but only one of the labour unions did. This could indicate that organisations and service providers focus more holistically on employee wellness than labour unions do. However, the nature of services they provide as part of their EWPs does not necessarily reflect this.

Most of the labour unions referred to health, occupational health and safety issues or legal requirements in their definitions of employee wellness. Although half of the organisations referred to health in their definitions, only one of the service providers did. Only one organisation referred to occupational health and safety in its definition and legal requirements was not a dimension that featured with either the organisations or service providers.
The literature reflects the same worrying situation. Authors define the concept differently. They often refer to 'employee well-being' (Noblet \& Rodwel, 2007, p. 2), 'wellness at work' (Hillier et al., 2005, p. 1), 'workplace wellness' (Wojcik, 2007, p. 3) and 'work related well-being' (Launis \& Pihlaja, 2007, p.604; Lindfors et al., 2007, p. 816).

Some authors see 'wellness' and 'health' as the same concept (DeMoranville, Schoenbachler \& Przytulski, 1998; Merina, 1992; Porter, 2005). Although the different terms all relate to improving employees through better health, fitness or otherwise, the focus of different organisations is not necessarily on improving the work-related issues of employees.

Therefore, in defining employee wellness, the organisations focused mostly on health, dimensions of wellness and positive work influences. The service providers focused mostly on the recognition of dual benefits to organisations and employees whilst the labour unions focused on legal requirements, occupational health and safety as well as health.

It is clear that the three groups differ in their definitions of employee wellness. In addition, labour unions strongly associated wellness with adherence to the legal requirements (the Occupational Health and Safety Act and other legislation that influences employees).

Although the definitions of the three important role-players in the employee wellness sphere in South Africa differ, the analyses of input from all of them present a broad and robust definition within which employee wellness can be conceptualised.

\section{Introducing Employee Wellness Programmes: Reasons and negative consequences}

There were also many different reasons that organisations introduced EWPs to their organisations. The main reasons were the high incidence of sick leave, high absenteeism and social responsibility. These reasons show that they are reactive in their approach and might indicate that organisations should start investigating the work factors that contribute to employees being sick and absent from work.

South Africa's HIV and Aids rate is of the highest in the world. This can also contribute to employees being sick. Work stress can affect the health of employees directly (McClenahan, Giles \& Mallett, 2007) and the current high levels of sick leave and absenteeism may be symptoms of already existing problems.

Social responsibility was another major reason that employers introduced EWPs to their organisations. The reason for this can be that organisations are beginning to draw a link between corporate social responsibility, improvements in their value to shareholders and the morale of employees. In addition, because organisations must list their corporate responsibility activities in government tenders, it 'pays' to invest in social responsibility (Van Den Ende, 2004). 
The fourth most reported reason that organisations introduced EWPs to their organisations was addressing stress, the occurrence of HR incidents and that many employees worked overtime. If organisations focused more on these issues, sick leave and absenteeism might reduce and employees may perceive the organisations as more caring.

Other reasons for introducing EWPs include:

- $\quad$ to reduce health care or medical costs (Anonymous, 2007; Janice \& Ho, 1997; Naydeck, Pearson, Ozminkowski, Day \& Goetzel, 2008; Pallarito, 2007)

- to increase employee productivity, welfare benefits and morale

- to improve the image of the company (Janice \& Ho, 1997)

- to improve staff morale and productivity (Watkins, 2003)

- to help employees to stop smoking, lose weight and monitor their blood pressure (L.D, 2007)

- to reduce absence because of sickness

- to improve retention, productivity and well-being (Brockett, 2007).

It is clear that there is a whole range of reasons why organisations introduce EWPs. The literature seems to focus more on issues of productivity and health, whilst the participating South African organisations focus more on reducing sick leave and meeting goals of social responsibility. Although there is an overlap in the reasons for introducing programmes that South African organisations offer and those the literature cites, most still relate to individual health issues and not on organisational issues that might affect the employee.

The main reasons service providers thought organisations introduced EWPs were that the organisations want to be seen as employers of choice, need to comply with occupational health and safety law, or to meet their goals of social responsibility.

Therefore, social responsibility was an important reason for organisations introducing EWPs. As employees in a developing country, many people in South Africa still live in poor conditions and do not always have access to good medical care. Therefore, whilst organisations can provide services like medical care and counselling services to their employees as wellness benefits, they can also claim to be acting in socially responsible ways to their employees and their families.

The main reasons labour unions thought organisations introduced EWPs were that the organisations want their employees to be more productive, they want to be seen as socially responsible, they want to comply with occupational health and safety law and want to retain employees.

It is important to note that, although labour unions and service providers think that one of the main reasons that organisations introduce EWPs is to comply with occupational health and safety law, only $3 \%$ of the participating organisations agreed. Possible reasons might be that organisations see other benefits to employee wellness or that they do not see how employee wellness initiatives can help them to comply with the Occupational Health and Safety Act. Although social responsibility emerged as a major reason for introducing the programmes for the surveyed stakeholders, one should view this conclusion with caution. For example, organisations may use their programmes as marketing tools rather than as employee benefits. Analysts have shown that, in South Africa, only 1\% of a R1.7 trillion investments go toward social responsibility (Finlay, 2004). Furthermore, perceptions of what 'socially responsibility' means may vary widely, especially where the objectives may compete. An example is organisations that aim to make profits and unions that aim to protect employees.

In introducing EWPs, the main problems about trust and confidentiality were more prevalent when the people who provided the EWP services were also employees of the organisation. One cannot overemphasise the importance of EWP personnel confidentiality in dealing with the sensitive issues of employees. In cases where trust and confidentiality problems arise, it may be wise to use a service provider to provide employee wellness services.

Therefore, ethical conduct for employees who service EWPs becomes an important issue. Other problems noted about introducing programmes related to providing services to remote locations. Organisations that use service providers can reduce the problem because service providers deliver many services that they can provide telephonically and via email or the Internet. The assistance of service providers with existing infrastructure might be a more cost-effective way of managing employee wellness. This is particularly true for smaller organisations that do not have the technological infrastructure to render these services.

\section{Presenting the results of Employee Wellness Programmes}

Almost all of the organisations presented the results of their EWPs to board meetings, business unit meetings or CEOs. Most of the organisations presented the results once or twice a year or every quarter.

With one exception, organisations presented the results of their programmes in-house. Therefore, one can assume that organisations do not use the results of the programmes to attract employees or stakeholders.

In order for organisations to use employee wellness for competitive advantage, they should market it for this reason. Because of a lack of research on employee wellness, there are no benchmarks about how often organisations should present results about EWPs.

However, organisations can use this information as a competitive tool and improve its visibility. Organisations should market it responsibly and base it on facts. 


\section{Success, effectiveness and improvement of Employee Wellness Programmes}

Organisations rated the success of their EWPs differently and gave different reasons for their ratings.

Many organisations defended their ratings by indicating that they provide a good range of services (EAP, counselling, HIV and health). However, very few referred to measurable and objective outcomes like reducing absenteeism or sick leave. Several referred to high, or increased, participation from employees as an indicator of success. However, one should not equate high uptake with success.

Two organisations indicated that their EWPs were less than effective because the wellness construct is not measurable. This relates again to the problem underlying the multiplicity of definitions - it is difficult to measure and operationalise a badly defined and poorly conceptualised construct.

In addition, where one organisation felt that using a service provider helped to make its programme successful, another organisation felt that poor reporting from the service provider made the programme less effective because it could not focus its interventions properly.

It is important, when measuring the effectiveness of EWPs, that an organisation must conduct an assessment to address the root causes of problems. In addition, after implementing any intervention, an organisations needs to conduct a reassessment to determine whether the intervention was successful or not. It is clearly necessary to give accurate and timely data to manage employee wellness. Kompier, De Gier, Smulders, and Draaisma (1994) suggest that organisations should perform audits and reviews to manage health and safety effectively. This will ensure that an organisation can measure the effectiveness and success of its EWP.

There are some differences in how organisations measure the effectiveness of their programmes.

Nearly half of the organisations indicated that they did not measure effectiveness but did consider things like utilisation rates, declines in absenteeism, people with HIV returning to work, reporting chronic diseases and buy-in from employees. In contrast, more than half of the organisations said that they did measure effectiveness and used utilisation rates and declines in absenteeism as measures of effectiveness.

Therefore, indicators of effectiveness, or understanding what should be indicators of effectiveness, differ between organisations.

The organisations that noted that they measure the effectiveness of their EWPs also indicated that extensive marketing, good planning, reaching more people and using exit interviews are good measures of effectiveness. However, none of these actually helps to determine effectiveness. However, these organisations also looked at declines in the numbers of suicides, the success of smoking cessation programmes and decreases in medical boardings. All of these could measure EWPs effectively.

One can conclude that it is difficult to measure the real effectiveness of these programmes because the measurement ultimately rests on the subjective perceptions of the organisations. However, one can suggest that improving positive employee outcomes and reducing negative employee outcomes could indicate the effectiveness of an EWP. These might include reducing stress and emotional exhaustion, improving social support at work (Taris et al., 2003), improving morale, increasing loyalty, improving employee relations, improving productivity, reducing absenteeism and reducing accidents (Andrew, 1999).

Most of the organisations felt that they could improve their service delivery by making their EWPs more holistic and integrated and by allocating more resources and personnel. The organisations also felt that it would be better to provide the EWPs in-house. In-house programmes can be custommade for organisations and EWP teams can work closely with managers to make sure the programmes align with business goals and issues around employees (Lesch, 2005).

However, organisations need to find a balance with managing perceptions of confidentiality.

\section{Employee needs and participation of employees in Employee Wellness Programmes}

A quarter of the organisations determined employees' needs four times (quarterly) a year. However, this was not an assessment of employee wellness in the organisations. Instead, the organisations asked employees what services they would like to be part of the EWP.

If organisations did a proper needs assessment, based on the state of employee wellness in the organisation (including ergonomic assessment), they could assess and address the types and intensity of interventions as well as the level of risk better. Simply asking employees what they think they need only gives a biased picture of the true state of affairs.

In addition, implementing interventions after an employee wellness assessment takes time and this might delay their effects. Sufficient time must elapse after implementing interventions to determine their effectiveness.

Not more than $50 \%$ of the employees participated in EWPs in eight organisations. One can attribute the low participation rates to a number of factors.

On the one hand, overloaded employees may see participation in the programmes as another demand, rather than as a resource. In addition, the programmes might not address the specific problems the employees are experiencing. A possible reason for this may be that most of the organisations did not conduct objective surveys to determine the problem areas 
before implementing 'solutions'. This probably resulted in the interventions not focusing enough on the real problems and needs of the organisations and their employees.

However, 12 of the organisations indicated that they consulted their employees when developing their programmes. In some instances, they consulted unions and wellness coaches. One can question the intensity of these consultations because participation rates may have been low.

\section{Expenditure and support from managers}

Most of the organisations had budgets to fund their EWPs. Some had a flat rate budget. This meant that they had a fixed amount per employee per year. In some cases, the budget the organisations had for their EWPs was less than R100 per person per year.

Organisations have to comply with the Occupational Health and Safety Act. However, many consider employee wellness a soft issue and not one that warrants investing the organisations' capital in order to improve organisational profitability.

SETAs can also play a major role in providing funds for training employee wellness practitioners for organisations.

Almost half of the organisations had allocated budgets supplemented by fee-for-service models to fund their EWPs. Most organisations expected their budgets for their employee wellness activities to increase in the following year. This might indicate that organisations are increasingly willing to invest more money in their EWPs.

Two of the participating organisations rated the support they receive from managers for employee wellness as excellent and one indicated that its support was 'average'. The results showed that 13 of the 16 organisations regarded their managers as supportive of EWP initiatives. This could be why most organisations expect their budgets for employee wellness to increase in the following year.

\section{Limitations and recommendations}

In order for organisations to offer the necessary employee wellness services to their employees, it is important that they start with proper assessments of the state of employee wellness in their organisations. Improvements in employee wellness will only become visible if organisations start to introduce focused interventions, because only then will organisations start addressing the causes of their employee wellness problems.

In addition, it is important that organisations monitor the wellness states of their employees in order to manage employee wellness in their organisations effectively. This will only become possible when they improve their information about employee wellness. In the end, an EWP should positively influence employee outcomes like productivity, satisfaction, presenteeism, industrial relations incidents, accidents and safety.
This study has limitations. The researchers suggest that larger samples are used in future studies. In addition, the researchers suggest that a standardised instrument is developed to examine wellness practices in the South African context. However, this would present challenges to researchers because organisations define, implement, manage and evaluate wellness very differently.

Another limitation to this study is the limited focus on qualitative data. In-depth interviews with the people who manage EWPs in South African organisations would yield richer information on wellness practices in the country.

\section{References}

Addley, K., McQuillan, P., \& Ruddle, M. (2001). Creating healthy workplaces in Northern Ireland: Evaluation of a lifestyle and physical activity assessment programme. Occupational Medicine, 51(7), 439-449. doi:10.1093/occmed/51.7.439, PMid:11719614

Allen, J.R. (1993). Organizational support plays integral role in shaping healthy lifestyles. Wellness Management, 9(3), 6-7.

Andrew, L. (1999). Wellness promotion: A people ready strategy. The Barbados Advocate, Business Monday, 6-7.

Anonymous. (2007). Can wellness programs cut medical claims and costs? Contractor's Business Management Report, 8, 1-7.

Ardell, D. (1985). The history and future of wellness. Dubuque, IA: Kendall/Hunt.

Bennet, J. (1999). Employee assistance also helps productivity. The Argus, Business Section, $3,3$.

Berridge, J., \& Cooper, C. (1994). The employee assistance program: Its role in organizational coping and excellence. Personnel Review, 23(7), 4-20. doi:10.1108/00483489410072190

Berridge, J., Cooper, C.L., \& Highley-Marchington, C. (1997). Employee assistance programmes and workplace counselling. New York: Wiley Publishers.

Brockett, J. (2007). QVC buys in to wellness. People Management, 13(7), 10.

Corbin, C.B., \& Pangrazi, R.P. (2001). Toward a uniform definition of wellness: A commentary. President's Council on Physical Fitness and Sports Research Digest, 3(15), 1-8.

Corbin, C.B., Lindsey, R., Welk, G.J., \& Corbin, W.R. (2002). Concepts of fitness and wellness: A comprehensive lifestyle approach (4th edn.). New York: McGraw Hill.

DeMoranville, C.W., Schoenbachler, D.D., \& Przytulski, J. (1998). Wellness at work. Marketing Health Services, 18(2), 14-24.

Derr, W.D., \& Lindsay, G.M. (1999). EAP and wellness collaboration. In J.M. Oher (Ed.), The employee assistance handbook (p. 305-318). New York: John Wiley \& Sons.

Dhanesar, A., \& Hales, A. (1994). From fitness to wellness: A case study. People Dynamics, 12(1), 26-31.

Finlay, A. (2004). Investing in social responsibility. Retrieved February 29, 2008 from http://www.southafrica.info/doing_business/economy/development/ socialindex.htm

Gerber, M. (1995). Employee assistance: Combining communication and organisational development. HRM, 11(4), 31-32.

Goetzel, R.Z., \& Ozminkowski, R.J. (2008). The health and cost benefits of work site health-promotion programs. Annual Review of Public Health, 29, 303-323. doi:10.1146/annurev.publhealth.29.020907.090930, PMid:18173386

Hemp, P. (2004). Presenteeism: At work - but out of it. Harvard Business Review, 82(10), 49-58. PMid:15559575

Highley, J.C., \& Cooper, C.L. (1994). Evaluating EAPS. Personnel Review, 23, 1-12. doi:10.1108/00483489410072226

Hillier, D., Fewell, F., Cann, W., \& Shepard, V. (2005). Wellness at work: Enhancing the quality of our working lives. International Review of Psychiatry, 17(5), 419-431. doi:10.1080/09540260500238363, PMid:16194820

Hooper, M. (2004). Employee well-being: A hard issue. People Dynamics, 22(3), 8-9.

Janice, T.S., \& Ho, C. (1997). Corporate wellness programmes in Singapore: Effect on stress, satisfaction and absenteeism. Journal of Managerial Psychology, 12(3), 177-189. doi:10.1108/02683949710174801

Kompier, M., De Gier, E., Smulders, P., \& Draaisma, D. (1994). Regulations, policies and practices concerning work stress in five European countries. Work \& Stress, 8, 296-318. doi:10.1080/02678379408256538

Korhonen, I., Lappalainen, R., Tuomisto, T., Koobi, T., Pentikainen, V., Tuomisto, M., \& Turjanmaa, V. (1998). TERVA: Wellness monitoring system. Proceedings of the 20th Annual International Conference of the IEEE Engineering in Medicine and Biology Society, 20, 1988-1991.

Launis, K., \& Pihlaja, J. (2007). Changes in production concepts emphasize problems in work-related well-being. Safety Science, 45, 603-619. doi:10.1016/j. ssci.2007.01.006 
L.D. (2007). Wellness may get better. CFO, 23(10), 24-24.

Leiter, M.P., \& Wahlen, J. (1996). The role of employee assistance counselors in addressing organization problems. Employee Assistance Quarterly, 12(1), 15-28. doi:10.1300/J022v12n01_02

Lesch, N.K. (2005). Motorola drives strategic initiatives through collaboration and interdependence. The Integration of Employee Assistance, Work/Life, and Wellness Services, 77, 203-217.

Lindfors, P.M., Meretoja, O.A., Toyry, S.M., Luukkonen, R.A., Elovainio, M.J., \& Leino, T.J. (2007). Job satisfaction, work ability and life satisfaction among Finnish anaesthesiologists. Acta Anaesthesiologica Scandinavica, 51, 815-822. doi:10.1111/j.1399-6576.2007.01343.x, PMid:17578460

Makrides, L. (2004). The case for workplace health promotion. Newsbeat of CACR, 12, 1-6.

Martin, T., Kirkcaldy, B.D., \& Siefen, G. (2003). Religiosity and health among German adolescents. Journal of Managerial Psychology, 18(5), 453-470. doi:10.1108/02683940310484044

Maslach, C., Schaufeli, W.B., \& Leiter, M.P. (2001). Job burnout. Annual Review of Psychology, 52, 397-422. doi:10.1146/annurev.psych.52.1.397, PMid:11148311

McClenahan, C.A., Giles, M.L., \& Mallett, J. (2007). The importance of context specificity in work stress research: A test of the Demand-Control-Support mode in academics. Work \& Stress, 27, 85-95. doi:10.1080/02678370701264552

Merina, A. (1992). Wellness at work. NEA Today, 10(6), 4.

Myers, D.W. (1984). Establishing and building employee assistance programs. Westport, C.T.: Quorum Books.

Naidoo, A.V., \& Jano, R. (2003). The role of EAPs the SA context. The Social Work Practitioner-Researcher: A Journal on the Application of Research in Practice, 15(2), 113-127.

Naydeck, B.L., Pearson, J.A., Ozminkowski, R.J., Day, B.T., \& Goetzel, R.Z. (2008). The impact of the Highmark Employee Wellness Programs on 4-year healthcare costs. Journal of Occupational \& Environmental Medicine, 50(2), 146-156. doi:10.1097/ JOM.0b013e3181617855, PMid:18301171

Noblet, A.J., \& Rodwel, J.J. (2007). Integrating job stress and social exchange theories to predict employee well-being. Academy of Management Proceedings, p. 1-6.

Pallarito, K. (2007). Weighing the benefits of wellness. Business Insurance, 41(15), 9-12.

Porter, M.V. (2005). Wellness at work. Association Management, 57(4), 49-54.

Ramanathan, C.S. (1992). EAPs response to personal stress and productivity: Implications for occupational social work. Social Work, 37(3), 234-239.
Renaud, L., Kishchuk, N., Juneau, M., Nigam, A., Tétreault, K., \& Leblanc, M. (2008) Implementation and outcomes of a comprehensive worksite health promotion programme. Canadian Journal of Public Health, 99(1), 73-77.

SETA. (2007). SETA definition. Retrieved October 24, 2007, from http://www. southafrica.info/doing business/economy/development/setas overview.htm

Shaughnessy, J.J., \& Zechmeister, E.B. (1997). Research methods in psychology (4th edn.). New York: McGraw-Hill.

Shaw, G., Alfonso, H., Howat, P.A., \& Corben, K. (2007). Use of pedometers in a workplace physical activity program. Australasian Journal of Podiatric Medicine, 41, 23-28.

SPSS. (2007). SPSS 15.0 for Windows. Chicago, IL: SPSS Incorporated.

Taris, W.T. Kompier, M.A.J, Geurts, S.A.E., Schreurs, P.J.G., Schaufeli, W.B, De Boer E., Sepmeijer, K.J., \& Wattez, C. (2003). Stress management interventions in the Dutch domiciliary care sector: Findings from 81 organizations. International Journal of Stress Management, 70, 297-325. doi:10.1037/1072-5245.10.4.297

Taute, F., \& Manzini, K. (2009). Factors that hinder the utilisation of the employee assistance programme in the Department of Labour. Social Work, 45(4), 1-9.

Terblanche, L.S. (1992). The state of the art of EAPs in SA: A critical analysis. In R. P. Maiden (Ed.), Employee assistance programmes in South Africa (p. 17-28). London: The Hawthorn Press.

Thøgersen-Ntoumani, C., \& Fox, K. (2005). Physical activity and mental well-being typologies in corporate employees: A mixed methods approach. Work and Stress, 19(1), 50-67. doi:10.1080/02678370500084409

Van Den Bergh, N. (2000). Where have we been...? Where are we going...? Employee assistance practice in the 21st century. Employee Assistance Quarterly, 16(1/2) 1-13. doi:10.1300/J022v16n01_01

Van den Ende, L. (2004). Corporate social responsibility in South Africa: Fact or fiction Unpublished master's dissertation in Business Management. Johannesburg: Rand Afrikaans University.

Watkins, J. (2003). Wellness beats output slump. People Management, 9(25), 12-12.

White, R.K., McDuff, D.R., Schwartz, R.P., Tiegel, S.A., \& Judge, C.P. (1996). New developments in employee assistance programs. Psychiatric Services, $47,387-$ 391. PMid:8689369

Wojcik, J. (2007). Employers spot link between health, profit. Business Insurance, 41(50), p. 120.

Zarkin, G.A., Bray, J.W., \& Qi, J. (2000). The effect of employee assistance programs use on healthcare utilization. Health Services Research, 35, 77-100. PMid:10778825, PMCid:1089116 